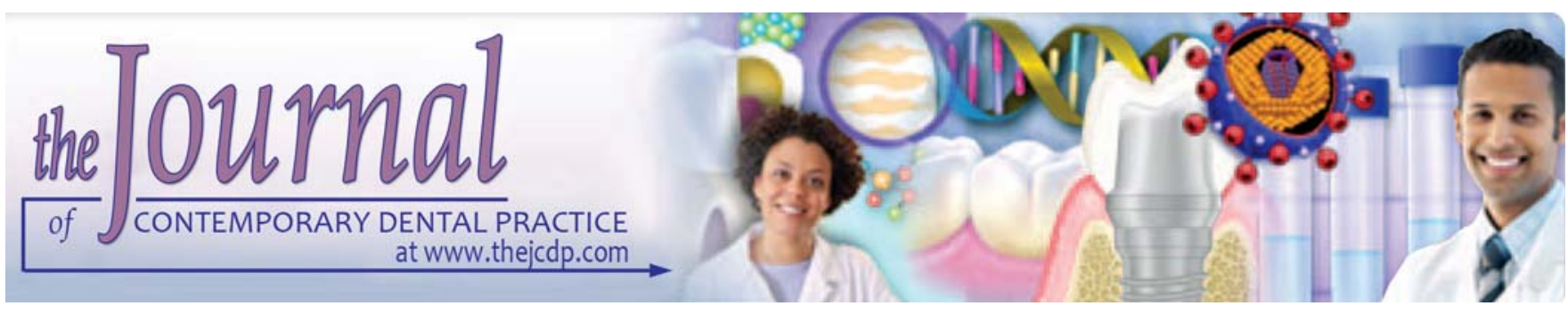

\title{
Anterior Restorations in Bleached Teeth: Difficulty Establishing the Color after Bleaching
}

\author{
Carolina Santezi, Mateus Rodrigues Tonetto, Cristina Dupim Presoto, Fernanda Ferreira Jassé \\ Osmir Batista de Oliveira Júnior, Marcelo Ferrarezi de Andrade, Renato de Toledo Leonardo
}

\begin{abstract}
It is becoming more common for patients to look for cosmetic procedures in dental offices. The search for lost or desired esthetics by patients is increasingly frequent and the professional must be able to meet this demand. To do this, dentists not only need to return the tooth back to its normal functioning state but also promote esthetic excellence. In this context, the association of cosmetic procedures, such as teeth whitening and restorative procedures, such as direct adhesive restorations is very common. The composite resins employed nowadays allow the reproduction of various optical properties of natural teeth. With these composite resins, it is possible to reproduce features such as translucency, opacity and specific features of the dental element, to bring back the esthetic harmony of the smile. This article reports a clinical case demonstrating the placement, in a stratified manner, of composite resins in bleached teeth, as well as the reproduction of optical and natural aspects of the teeth. In order to achieve esthetic and functional success of the restored procedure, it is important to be familiar with the new techniques and new materials in the market and above all, we must know when and where to use them.
\end{abstract}

Keywords: Bleached teeth, Dental esthetics, Composite resin.

How to cite this article: Santezi $C$, Tonetto MR, P resoto $C D$, J assé FF, de Oliveira OB J unior, de Andrade MF, de Toledo Leonardo R. Anterior Restorations in Bleached Teeth: Difficulty Establishing the Color after Bleaching. J Contemp Dent P ract 2012;13(5):735-739.

\section{Source of support $\mathrm{Nil}$}

Conflict of interest: None declared

\section{INTRODUCTION}

It has become increasingly common in the clinical practice to come across patients who are in search of cosmetic procedures, since the presence of an esthetically pleasing smile directly affects the individual's social life. Therefore, it is extremely important that the professional is able to meet the demand of function and esthetics as desired by the patient. ${ }^{1,2}$
The emergence of adhesive materials to tooth structure allows the dentist with the opportunity to enjoy more conservative and esthetic dentistry. With the new technological advances in dental materials, it is now possible to reproduce the lost dentin and enamel as well as individual characteristics almost indiscernibly. The current composite resins offer different shades (color name), chroma (color intensity) and value (degree of brightness), allowing mimicked optical characteristics of natural teeth, such as fluorescence, opalescence and translucence, which is extremely relevant when it comes to restorations in anterior teeth. . $^{2-6}$

In bleached teeth, even those who wait for 15 days to achieve a stabilized color, the color choice becomes a difficult task, since the teeth are replaced with a higher value of lightness. Because of this a lot of professionals tend to make mistakes, with restorative procedures resulting in either gray (low value) or too white (high value), ${ }^{7,8}$

Nowadays, due to the strong demand for esthetic treatment, including tooth whitening, bleaching composite resins has become essential. There are multi ple trademarks that have composite resins with specific colors for teeth that have undergone this esthetic procedure. Colors like B 1, B 0.5, and composite resins with high value have become common for professionals working in the field of esthetics. It is important to accentuate, however, that to mimic the real appearance of teeth, one must understand all factors associated with natural composite resin restorations. Thus, the professional must know how and where to use these materials and always obey the natural stratification. $^{3-5}$

This paper aims to demonstrate, using a clinical case, the concept of anterior restoration with stratified layers of a bleached tooth, giving it individual characteristics. 


\section{CASE REPORT}

Patient 22-year-old, male, came to the clinic of Restorative Dentistry, A raraquara Dental School (UNESP) reporting dissatisfaction with the yellowing of the Class IV restoration involving the mesial surface of element 21 which became more evident after performing tooth whitening (Fig. 1). No changes in pulp and periodontal tissues were noted after a detailed clinical and radiographic examination.

First a prophylaxis was performed with pumice and water for later verification and matching the color according to the technique of stratification in layers, where colors of composite resins were selected for enamel and dentin (Fig. 1). For the dentin layer located in the middle and the making of mamelons the dentin shade A 2 Z350 Filtek Supreme XT (3M-ESPE) was chosen. A body composite resin (A 2 B ody Z350 Filtek SupremeX T-3M ESPE), which has an intermediate opacity between those of enamel and dentin, was also used to mask the line of union enamel/ composite resin. For the enamel, the $A 1$ and $B 1$ colors were selected, both Z350 Filtek Supreme XT (3M -ESPE), where the first was used for reproduction of the palatine enamel or 'palatine shell' and the incisal third of the buccal. The second was used for production-specific characteristics of the patient's teeth such as white spots in the proximal and incisal.

In order to assist in the construction of the palatine wall, a palatine guide was made of condensation silicone obtained from the diagnostic waxing (Fig. 2), and its adaptation was found in the upper jaw.

A bsolute isolation was carried out on the upper front teeth and the previous substandard restoration was removed using a diamond cutting 1149 (K G Sorensen). A short bevel was performed (2135FF-KG Sorensen) in order to mask the bond line dental substrate/composite resin.

The phosphoric acid 37\% (Villevie) was applied to the dentin and enamel for a duration of 15 to 30 seconds respectively. The surface was thoroughly washed with water for 30 seconds to remove the acid. The excess water was removed from the dentin with the aid of sterile paper points and then the enamel was dried with light blasts of air. A microbrush dampened with a $2 \%$ chlorhexidine solution was then applied to the dentin for 60 seconds. It has been shown that this procedure inhibits the metalloproteinases ${ }^{9}$ enzymes that can be activated during phosphoric acid etching ${ }^{10}$ and are able to degrade the hybrid layer over time. ${ }^{11-13}$ Thus, it is expected to increase the longevity of the composite resin restoration.

The next step was hybridizing the dental structure using a three-step total-etch adhesive system (A dper Scothbond M ulti-purpose, 3M ESPE). The making of the palatal enamel was initiated with the aid of a condensation silicone guide.
A thin layer of composite resin A 1 E - Z350 Filtek Supreme $X T$ (3M-ESPE) was placed in the palatine guide, which was held in position and photoactivated for 40 seconds (Fig. 3).

The dentin resin layer was inserted, in the color A 2 D-Z350 Filtek Supreme X T (3M-ESPE). This mass of resin was then used to manufacture the dentinal mamelons. A fter this the body portion of the resin (A 2 Body Z350-Filtek

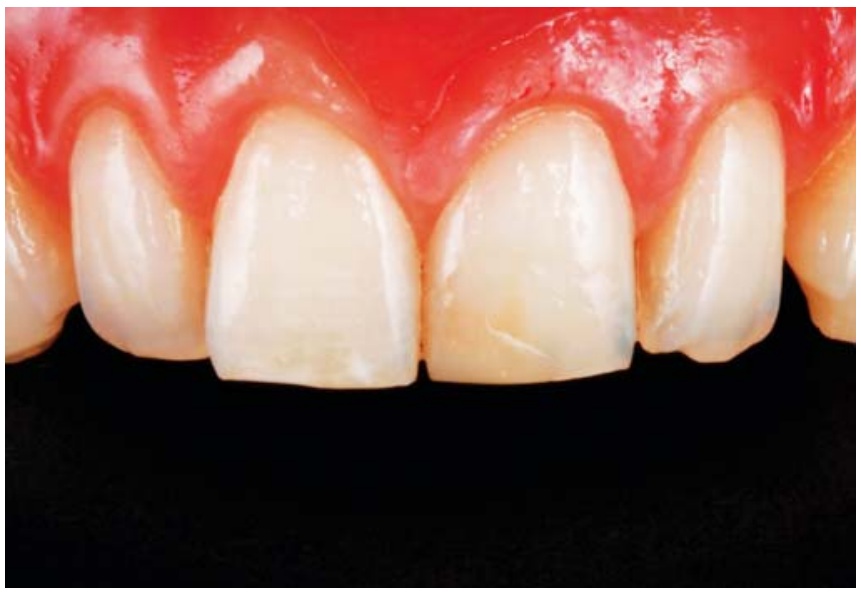

Fig. 1: Initial photo

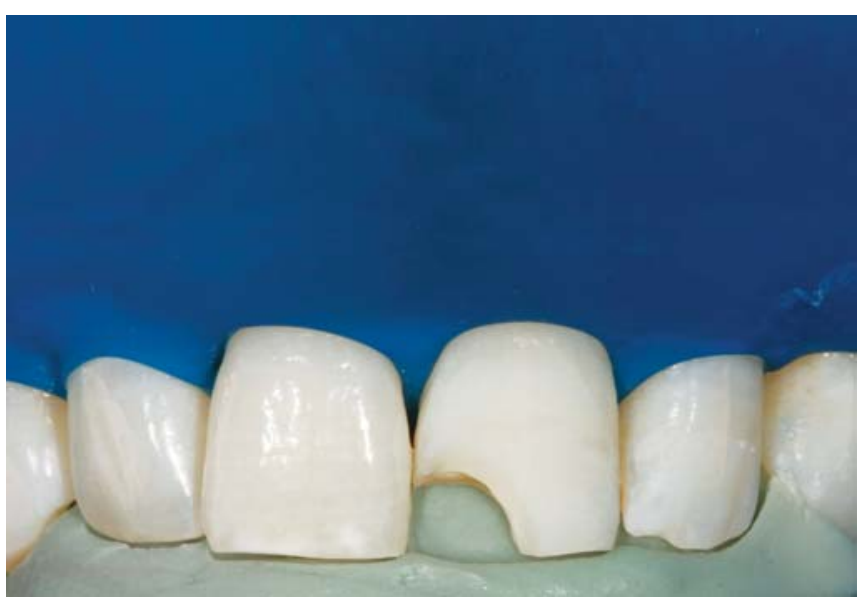

Fig. 2: Silicone wall

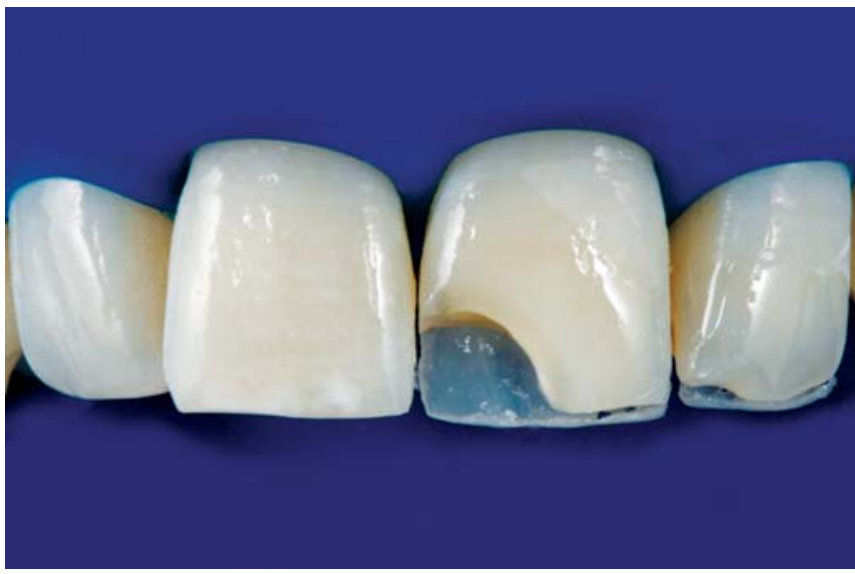

Fig. 3: Built palatine enamel 
Supreme XT-3M ESPE) was placed on the resin dentin and extended up to half of the bevel to mask the bond line dental substrate/restoration (Fig. 4).

Composite resins for characterization were al so inserted, such as translucent composite resin (Z350 Filtek Supreme $X T-3 M E S P E)$ in the region between the dentinal mamelons. Small portions of resin B 1 E Z350 Filtek Supreme XT (3M-ESPE) were placed in the incisal and proximal. The photoactivation was started and then the enamel shade was placed and photoactivated once (Figs 5 and 6).

Finishing burs $F$ and $F F$ series (2135FF in the buccal region and $3118 \mathrm{FF}$ on the palatine face- $\mathrm{K} \mathrm{G}$ Sorensen) were then used. A fter 1 week, the polishing was done with sanding disks Soflex Pop-On (3M-ESPE) to provide greater brightness and smoothness of the restoration and to leave it with a more natural appearance and prevent the adhesion of plaque (Figs 7 and 8 ).

\section{DISCUSSION}

Selecting the appropriate composite resin that simulates the physical and optical properties of enamel and dentin can

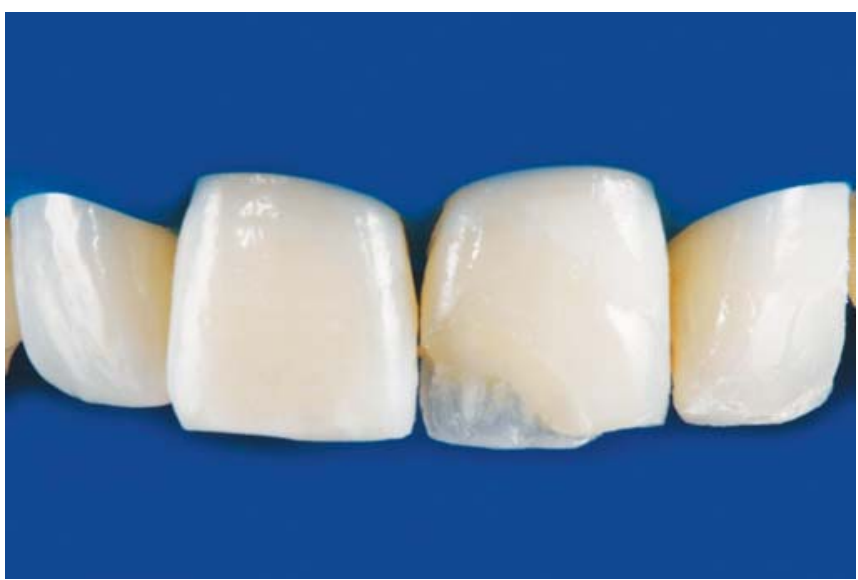

Fig. 4: Insertion of dentin resin, body, incisal effect, opaque resin and characterization of white

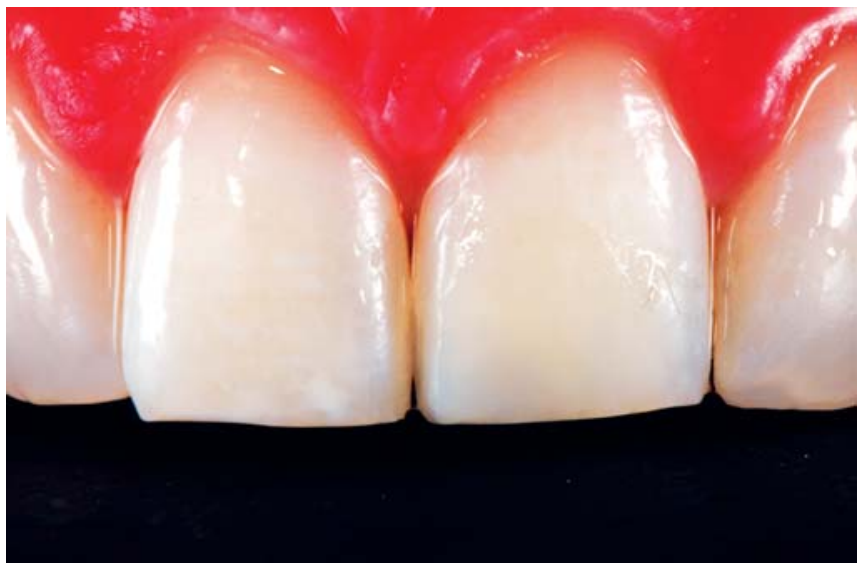

Fig. 5: Profile after built and polymerization of buccal enamel determine the success of an esthetic and functional restoration. The relationship between color and color contrast are optical characteristics and are important when choosing an appropriate restorative material.

The natural layering technique is undoubtedly the best way to optimize the use of these composite resins. ${ }^{14,15} \mathrm{This}$ allows sequential construction of the palatal/lingual enamel, the body of dentin and the buccal enamel. It is also possible

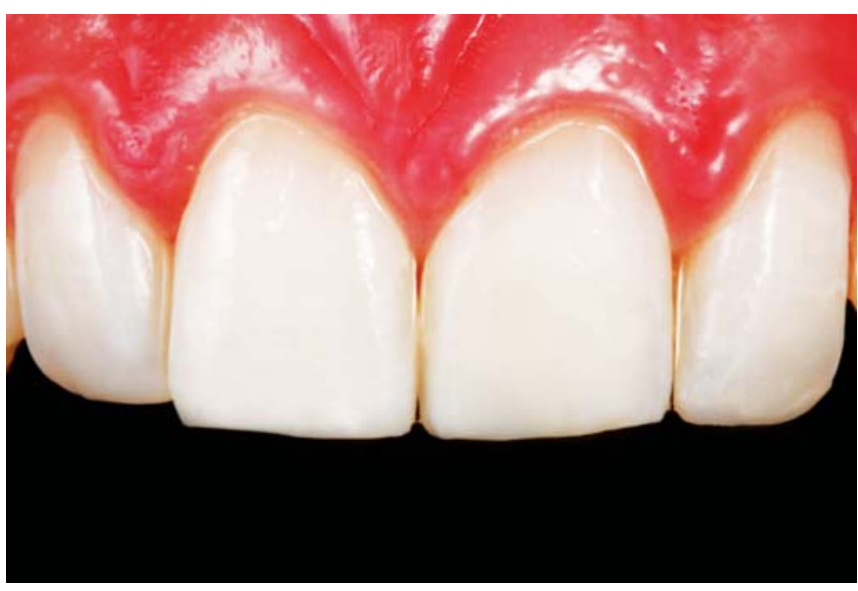

Fig. 6: Final aspect after esthetic restoration

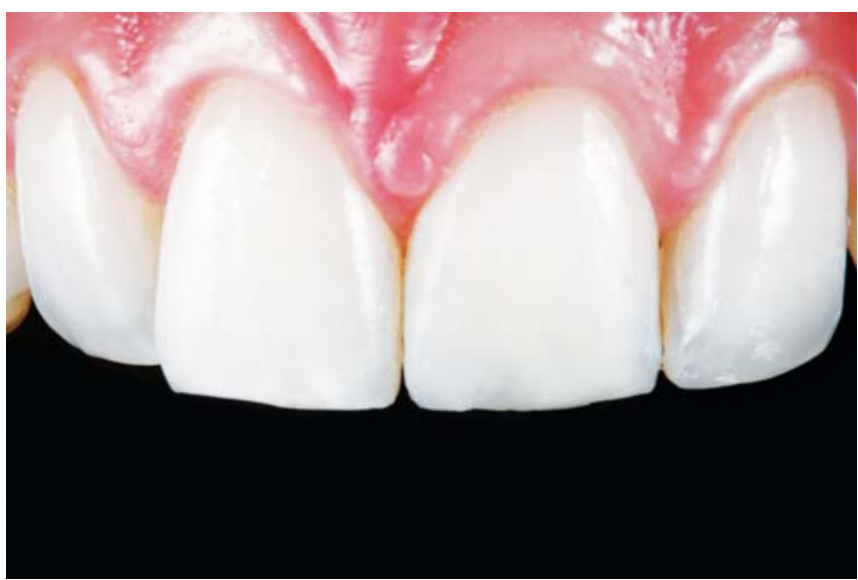

Fig. 7: Profile after 1 week, before polishing

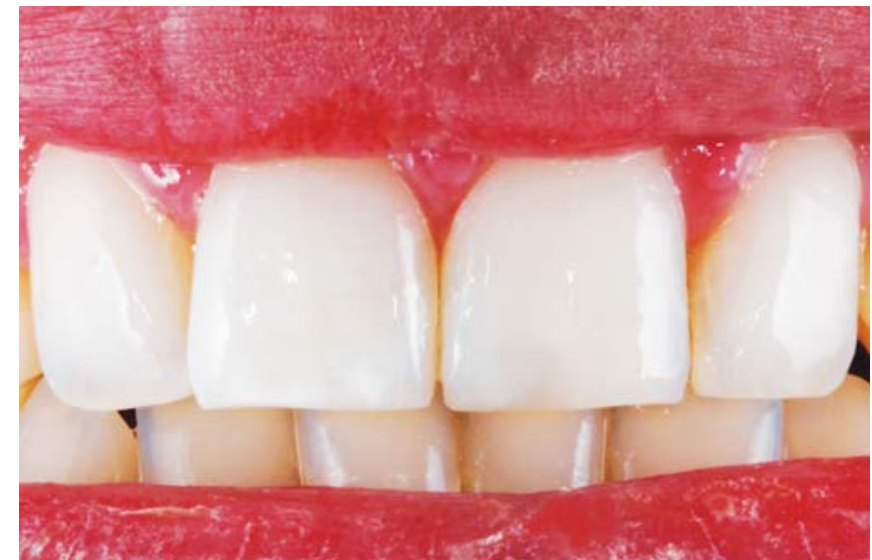

Fig. 8: After polishing 
to characterize spots, grooves or cracks forming part of the dental anatomy. ${ }^{16}$

B leached teeth have a higher luminosity, in other words, its value becomes greater, since it reflects more light than it absorbs. It is important to understand that composite resins (dentin resins, body resins and even resins used to mask stained teeth) have higher luminosity than more translucent composite resins. Such information is extremely important when it comes to restorative/esthetic treatment in whitened teeth. ${ }^{17}$

Nowadays, there are a range of compounds developed especially for use in bleaching. For example, L, XL, XX L (4-Seasons, Ivoclar V ivadent), SL, SSL (D urafil, Heraeus Kulzer), W, XL, WO, WE (Esthet-X, Dentsply- Caulk), $X W E, X W B, X W D, W D, W B, W E$ (Filtek Supreme, 3M ESPE)

It is important to note that these resins are quite opaque and therefore a translucent layer is needed for covering this portion of the tooth in order to establish the natural restoration. The thickness of this resin's layer on the bleached teeth will directly influence more or less plainness to the restoration. It is extremely important for this layer to be thin.

Due to the development of specific bleaching composites, within the same brand, these composites are expected to have higher luminosity and be more opaque than conventional resins. Surprisingly, few composites developed for bleached teeth have the same brightness as conventional resins. ${ }^{18}$

Tooth bleaching can result in a variety of tones often more luminous and or yellowish than the VITA Classical, which is the most widely used worldwide. Lest there be any confusion, personalized color scales should be used when choosing colors for bleached teeth restorations. ${ }^{7,8}$

\section{FINAL CONSIDERATION}

W ith the addition of technical improvements, the pursuit of knowledge, and the availability of resins it is in the dentists hands to ensure patient satisfaction and restore harmony to their smile.

\section{REFERENCES}

1. Baratieri L N . Estética: R estaurações adesivas diretas em dentes anteriores fraturados. São Paulo: Santos 1995.

2. Carrilho EV P, Paula A, Tomaz J. Terapêuticas estéticas integradas no âmbito da dentistaria operatória. Rev Port Estomatol Cir M axilofac $2007 \mathrm{~J}$ an-M ar;48(1):23-34.

3. Dietschi D. Free-hand composite resin restorations: $A$ key to anterior aesthetics. Pract Periodontics A esthet D ent 1995 Sep; 7(7):15-25.

4. Dietschi D. Free-hand bonding in the esthetic treatment of anterior teeth: Creating the illusion. J Esthet Restor D ent 1997 J ul; $9(4): 156-64$
5. Dietschi D. L ayering concepts in anterior composite restorations. J Adhes Dent 2001 Spring;3(1):71-80.

6. Tonetto M R, de Oliveira OB J r, Campos EA, Saad J RC, D antas AA R, R astelli ANS, Porto N eto ST, A ndrade M F. Fluorescence level of composites assessed by computer processing of digital images: Scan white. World J Dent 2012;3:141-44.

7. K abbach W, Zezell D M , B andéca M C, A ndrade M F. The effect of power bleaching actived by several light sources on enamel microhardness. Laser Phys 2010 J ul;20(7):1654-58.

8. Silva Costa $S X, B$ ecker $A B$, de Souza Rastelli A N, de Castro M onteiro L offredo L, de A ndrade M F, B agnato V S. Effect of four bleaching regimens on color changes and microhardness of dental nanofilled composite. Int J Dent 2009;31:38-45.

9. Gendron R, Grenier D, Sorsa T, M ayrand D. Inhibition of the activities of matrix metalloproteinases 2, 8 and 9 by chlorhexidine. Clin Diagn Lab Immunol 1999 M ay;6(3):437-39.

10. Pashley DH, Tay FR, Y iu C, Hashimoto $M$, B reschi $L$, Carvalho RM, Ito $\mathrm{S}$. Collagen degradation by host-derived enzymes during aging. J Dent Res $2004 \mathrm{M}$ ar;83(3):216-21.

11. Carrilho M R, Tay FR, Donnelly A M, A gle KA, Tjaederhane L, Mazzoni $A, B$ reschi $L$, Foulger $S$, Pashley $D H$. Host-derived loss of dentin matrix stiffness associated with solubilization of collagen. J Biomed M ater Res B A ppl Biomater 2009 J ul;90B (1): 373-80.

12. Birkedal-Hansen H. M atrix metalloproteinases. Adv Dent Res 1995 N ov;9(3 Suppl):16.

13. Ricci HA, Sanabe ME, de Souza Costa CA, Pashley DH, Hebling J. Chlorhexidine increases the longevity of in vivo resindentin bonds. Eur J Oral Sci 2010 A ug;118(4):411-16.

14. M ondelli J. Remodelação cosmética. In: Estética e cosmética em clínica integrada restauradora. São Paulo: Q uintessence 2003.

15. Walker $\mathrm{R}$, Burgess $\mathrm{J}$. Comparing resin-based composites. Compend Contin Educ D ent 2004 J un;25(6):424-28.

16. Hirata R, A mpressan RL, Liu J. Reconstrução de dentes anteriores com resinas compostas: uma seqüência de escolha e aplicação de resinas. J BC J B ras Clin Estet Odontol 2001 JanFeb;5(25):15-25.

17. da Costa J, V argas M, Swift EJ J r, A nderson E, Ritter S. Color and contrast ratio of resin composites for whitened teeth. J D ent 2009; 37 (Suppl 1):e27-33.

18. K amishima N, I keda T, Sano H. Color and translucency of resin composites for layering techniques. Dent M ater J 2005 Sep; 24(3):428-32.

\section{ABOUT THE AUTHORS}

\section{Carolina Santezi (Corresponding Author)}

Master's Student, Department of Restorative Dentistry UNESP, A raraquara (FOA r), São Paulo, B razil, Humaitá St, 1680 CEP: 14801-903, Phone: 5516 3307-1853/55 16 8114-3400 e-mail: carolina_santezi@ hotmail.com

\section{Mateus Rodrigues Tonetto}

M aster's Student, Department of Restorative Dentistry, UNESP A raraquara (FOA r), São Paulo, B razil

\section{Cristina Dupim Presoto}

M aster's Student, Department of Restorative Dentistry, UNESP A raraquara (FOA r), São Paulo, B razil 
Anterior Restorations in Bleached Teeth: Difficulty Establishing the Color after Bleaching

\section{Fernanda Ferreira Jassé}

Doctoral Student, Department of Restorative Dentistry, UNESP A raraquara (FOA r), São Paulo, B razil

\section{Osmir Batista de Oliveira Júnior}

Professor, Department of Restorative Dentistry, UNESP, A raraquara (FOA r), São Paulo, Brazil

\section{Marcelo Ferrarezi de Andrade}

Professor, D epartment of R estorative Dentistry, UNESP, A raraquara (FOA r), São Paulo, Brazil

\section{Renato de Toledo Leonardo}

Professor, D epartment of Restorative Dentistry, UNESP, A raraquara (FOA r), São Paulo, B razil 